\title{
Peran Penting Keimigrasian dalam Masalah Penyeludupan Manusia dan Perdagangan Orang
}

\author{
Arsyad Imam Baihaqi, Endra Inggita Sabriyartendra*, Salsabila Putri Salam \\ Program Studi Hukum Keimigrasian, Politeknik Imigrasi \\ *Correspondence email: endrainggita96@gmail.com
}

\begin{abstract}
Abstrak. Kejahatan perdagangan manusia masih menjadi topik utama dalam pembahasan dunia sekaligus titik perhatian paling mencolok karena keseriusan masalahnya. Perdagangan orang merupakan masalah utama globalisasi modern karena keberadaan tindak kejahatan tersebut telanjur menjadi epidemi di banyak negara. Tujuan penelitian ini untuk mengetahui bagaimana terjadinya proses Penyelundupan Manusia (People Smuggling) dan Perdagangan Orang di Indonesia, Dasar Hukum serta Penegakan Terhadap Tindak Pidana Penyelundupan dan Perdagangan Manusia. Serta Proses Pertanggung jawaban bagi para pelaku Tindak Pidana Penyelundupan dan Perdagangan Manusia. Dengan menggunakan metode Penelitian deskriptif ialah metode yang digunakan dalam penelitian ini, metode ini mempunyai tujuan untuk mendeskripsikan hal yang berlaku saat ini, diantaranya adalah upaya untuk menggambarkan suatu hal atau mendeskripsikan, mencatat, menganalisis dan menjelaskan kondisi saat ini (aktual). Dan akan didapatkan hasil yaitu kejahatan perdagangan orang (human trafficking) ini, pelaku menggunakan berbagai jalan demi kelancaran kejahatannya. Selanjutnya Aturan mengenai Penyelundupan Manusia dan Perdagangan Orang di Indonesia tercantum dalam beberapa aturan perundang-undangan, yakni UU Nomor 6 Tahun 2011, perihal Keimigrasian. Lalu dalam Pertanggungjawaban pidana, orang yang melakukan tindak pidana penyelundupan orang dan perdagangan manusia didasarkan pada ketentuan UU No. 6 Tahun 2011 mengenai Keimigrasian.
\end{abstract}

Kata kunci: Penyeludupan Manusia; Perdagangan Orang; Pidana Keimigrasian

Abstract. The crime of human trafficking is still a major topic in world discussion as well as the most striking point of attention because of the seriousness of the problem. Trafficking in persons is a major problem of modern globalization because the existence of this crime has already become an epidemic in many countries. This research aim to find out how the process of People Smuggling and Trafficking in Indonesia occurs, the legal basis and enforcement of the crime of people smuggling and trafficking. As well as the Accountability Process for the perpetrators of the Crime of Smuggling and Human Trafficking. By using descriptive research method is the method used in this study, this method has the aim of describing things that are currently in effect, including efforts to describe something or describe, record, analyze and explain current (actual) conditions. And the results will be obtained, namely the crime of human trafficking, the perpetrators use various ways to smooth the crime. Furthermore, the Rules regarding Human Smuggling and Trafficking in Persons in Indonesia are contained in several laws and regulations, namely Law Number 6 of 2011, concerning Immigration. Then in criminal liability, people who commit criminal acts of people smuggling and human trafficking are based on the provisions of Law no. 6 of 2011 concerning Immigration.

Keywords: Human Trafficking; Immigration Crime; People Smuggling

\section{PENDAHULUAN}

Karena pesatnya perkembangan teknologi dan informasi, batas-batas antar negara menjadi kabur. Akibat dari adanya globalisasi pasar bebas antar negara akhirnya terbuka lebar hingga terbuka pula peluang bagi setiap negara untuk memenuhi kebutuhan masyarakatnya tanpa terbatas ruang dan waktu. Peningkatan mobilitas orang dan barang dari tempat ke-satu menuju tempat lain, atau dari negara satu ke negara lainnya pun terjadi karena akses antar negara juga menjadi lebih luas. Dengan terbukanya pintu masuk dan akses dalam lingkup tanah ini, mendukung setiap individu untuk dengan gampang berpindah dari tempat satu ke tempat lainnya. Fenomena ini menyebabkan beberapa upaya untuk menjaga keamanan dan keselamatan negara melalui perumusan kebijakan keimigrasian untuk mencegah perdagangan manusia (human trafficking) dan penyelundupan orang (people smuggling) di Indonesia.

Tindak kejahatan maritim adalah jenis kejahatan yang terjadi dalam kawasan perairan sebuah negara. tindak kejahatan ini tersebar luas di kawasan kepulauan seperti laut, selat dan juga samudera. Topik kejahatan laut kini menjadi topik internasional karena kejahatan tersebut tidak hanya bersifat nasional tetapi juga lintas batas (Transnational Organized Crimes). Pelakunya bisa terdiri lebih dari satu negara dan mereka terorganisir dengan baik. Sampai dengan saat ini, jalur perdagangan yang sangat strategis adalah laut, karena nyaris $90 \%$ perdagangan dunia diangkut via armada laut (Nasution, 2017). Menurut Nasution (2017) : Penjualan Obat terlarang illegal (Trafficking in Illegal Drugs), Penjualan Ilegal Manusia (Human Trafficking), Manusia yang diselundupkan (People Smuggling), Penyelundupan Alat dan Senjata Perang (Arms Smuggling), Pencucian Uang (Money Laundering), dan Jual-beli Senjata serta alat perang ringan dan berat (Small Arms and Light Weapon Trafficking) Merupakan jenis kejahatan transnasional.

Penyelundupan manusia adalah bentuk kejahatan itu sendiri, karena hukum imigrasi tidak ditegakkan secara hukum dan menyebabkan masalah bagi para 
imigran. Trafficking adalah suatu bentuk tindak kejahatan lintas batas terorganisir yang mengakibatkan masalah di hampir semua negara, tidak terkecuali Indonesia yang dijadikan sebagai negara transit bagi para pelaku perdagangan orang. Sebagaimana didefinisikan dalam Pasal 3 tentang Protokol Perdagangan Manusia PBB tahun 2000, pelaku perdagangan orang berusaha untuk secara langsung ataupun tak langsung memperoleh keuntungan material atau signifikan lainnya, baik dari invasi ilegal ke bagian negara mana pun. pelaku bukan warga negara dan tidak memiliki izin tinggal.

Tidak seperti perdagangan manusia, penyelundupan ditandai dengan adanya kesepakatan yang terjadi antara penyelundup dan pelanggan. perjanjian kontrak kesepakatan ini biasanya berakhir ketika Anda tiba di tempat tujuan. Namun, situasi penyelundupan sebenarnya bias menjadi keadaan yang bisa dijelaskan dengan pelanggaran HAM yang ekstrem, dan imigran yang disusupkan diancam, dilecehkan, dieksploitasi, disiksa, dan bahkan dibunuh oleh penyelundup. Penyelundup juga dapat diperdagangkan, misalnya jika mereka ditipu oleh kondisi peran mereka untuk mengeksploitasi tenaga kerja (Gallagher, 2014).

Kejahatan perdagangan manusia masih menjadi topik utama dalam pembahasan dunia sekaligus titik perhatian paling mencolok karena keseriusan masalahnya. Perdagangan orang merupakan masalah utama globalisasi modern karena keberadaan tindak kejahatan tersebut telanjur menjadi epidemi di banyak negara. Dalam IOM GIFT dan UN untuk korban untuk dieksploitasi orang berdasar pada jenis kelamin dan usia, wanita dewasa paling banyak dibandingkan dengan pria dewasa. Perbudakan manusia kini sudah berubah bentuk menjadi perdagangan (eksploitasi) manusia yang merupakan bentuk dari terlanggarnya harkat serta martabat manusia.

Korban diperjual-belikan tak hanya untuk prostitusi, namun juga mencakup wujud eksploitasi yang lainnya, seperti pelayanan paksa (kerja paksa), perbudakan (penyerahan diri secara paksa) dan atau tindakan yang sama dengan tindak perbudakan tersebut. Pelaku tindak kejahatan ini melakukan perekrutan (penerimaan), pengantaran, pemindahan (evakuasi), penyembunyian (menutupi) ataupun penerimaan korban dengan tujuan untuk dijerumuskan, dijebak, atau dimanfaatkan dalam praktik eksploitasi atau pemanfaatan paksa dengan segala bentuknya dengan ancaman dan atau penggunaan pukulan (kekerasan), penculikan, pemalsuan, penipuan, penggelapan, dan jualbeli kekuasaan (posisi rentan), memberi bayaran materi atau keuntungan lainnya sehingga mendapat persetujuan dari seseorang yang punya kontrol penuh yang dapat mengontrol korban (UU Nomor 21 Tahun 2007). yakni:
1. Bagaimana Terjadinya Penyelundupan Manusia (People Smuggling) dan Perdagangan Orang di Indonesia?

2. Apa Dasar Hukum serta Penegakan Terhadap Tindak Pidana Penyelundupan dan Perdagangan Manusia?

3. Bagaimana Pertanggung jawaban bagi para pelaku Tindak Pidana Penyelundupan dan Perdagangan Manusia?

\section{METODE}

Penelitian deskriptif ialah metode yang digunakan dalam penelitian ini, metode ini mempunyai tujuan untuk mendeskripsikan hal yang berlaku saat ini, diantaranya adalah upaya untuk menggambarkan suatu hal atau mendeskripsikan, mencatat, menganalisis dan menjelaskan kondisi saat ini (aktual). Dengan kata lain penelitian deskriptif mempunyai tujuan untuk mendapatkan informasi tentang keadaan atau kondisi saat ini, dan melihat hubungan antar beberapa variable yang ada. Penulis tidak mengggunakan hipotesis atau menguji hipotesis namun hanya menggunakan dan menggambarkan informasi senyata dan apa adanya sesuai pada variabel yang sedang diteliti. Selain itu, penelitian ini juga menggunakan penelitian kualitatif.

penelitian kualitatif merupakan penelitian mengenai riset yang bersifat menggambarkan keadaan (deskriptif) dan banyak memakai teknik analisa. Penelitian ini lebih menonjolkan bagian Proses dan makna (perspektif subjek). Pemandu penelitian ini memanfaatkan landasan teori supaya fokus penelitian bisa faktual dan aktual seperti kondisi saat ini. Di samping itu landasan teoripun bermanfaat untuk memberikan gambaran umum yang luas mengenai latar penelitian dan sebagai topik bahasan hasil penelitian.

\section{HASIL DAN PEMBAHASAN}

\section{Terjadinya Penyelundupan Manusia (People Smuggling) dan Perdagangan Orang}

Zaman yang semakin modern membuahkan kebutuhan yang semakin tinggi, aspek sosial-budaya masyarakat yang ingin mendapatkan keuntungan besar dengan rentan waktu yang singkat. Melihat kondisi ekonomi masyarakat Indonesia yang tergolong menengah, masih banyak daerah-daerah Indonesia yang tingkat ekonomi penduduknya bahkan menengah kebawah. Salah satu faktor penting juga yang menyebabkan di Indonesia banyak sekali penyelundupan manusia ataupun perdagangan orang ialah karena letak geografis Indonesia yang sangat besar, dan mempunyai pulau-pulau kecil yang tidak berpenghuni dan dekat dengan perbatasan negara lain.

Banyak daerah-daerah didekat perbatasan dengan negara tetangga yang dijadikan tempat penampungan sementara dengan memberikan imbalan kepada wargawarga setempat agar mau membantu memperlancar usaha nya. Negara Indonesia juga dikenal sebagai negara transit untuk para imigran, keberadan imigran illegal ini 
lambat laun akan menimbulkan banyak tindak kejahatan dalam segi kuantitas dan kualitas. faktor ekonomi dan perdagangan (bisnis) bebas yang luas atau longgarnya lembaga penegak hukum di Indonesia bukan alasan utama adanya kejahatan lintas batas. Namun, wilayah geografis Indonesia sendiri adalah faktor peendukungnya. Indonesia merupakan negara kepulauan yang mempunyai beberapa pintu masuk melalui pelabuhan, bandar udara, perbatasan perairan dan darat (Fernando, 2013).

Kemiskinan adalah salah satu faktor yang paling dominan (paling banyak) dalam perkembangan tindak kejahatan ini (perdagangan manusia) dan perdagangan manusia. Penyelundupan manusia biasanya terjadi karena adanya persetujuan orang atau kelompok organisasi yang akan diselundupkan, dan alibi yang paling general menjadi latar belakang ialah iming-iming kesempatan memiliki pekerjaan guna meningkatkan status sosial ekonomi mereka, harapan kehidupan yang jauh lebih baik untuk diri mereka sendiri dan keluarga. Penyelundupan manusia sebenarnya didasari oleh keinginan untuk menjadi ilegal. Orang dengan standar hidup yang rendah dapat dengan mudah dibujuk untuk menjual dengan cara yang menciptakan lapangan kerja untuk kehidupan yang lebih baik. Situasi ini diperparah oleh populasi utama negara dan masalah pekerjaan, terutama di kalangan perempuan. Untuk meringankan tindak pidana perdagangan orang ini, para pelaku biasanya menggunakan atau memakai berbagai cara licik, ada yang diculik lalu dijual ke prostitusi luar negeri, ada juga yang dijual oleh keluarganya sendiri yang percaya jika anaknya akan dijadikan pasisten rumah tangga (pembantu) atau melakukan pernikahan kontrak dengan berbagai tujuan dengan orang asing (WNA) dan cara yang terakhir adalah dengan menipu korban yang bekerja di tempat tertentu, tapi kemudian justru dijual di kawasan prostitusi.

People smuggling sesungguhya terjadi karena terdapatnya dorongan dari diri sendiri untuk menjadi seorang imigran gelap (ilegal). Orang-orang yang memiliki tingkat kehidupan menengah ke bawah akan lebih mudah untuk dibujuk oleh motif pemberian pekerjaan guna status sosial dan kehidupan yang jauh lebih baik. Kondisi ini diperkuat lagi karena jumlah penduduk suatu negara yang besar dan kesulitan mendapat pekerjaan khususnya bagi para wanita.

Sedangkan untuk memudahkan kejahatan perdagangan manusia (human trafficking) ini, para pelaku menggunakan berbagai cara, ada yang diculik dan kemudian dijual ketempat prostitusi luar negeri, ada pula yang dijual oleh keluarganya sendiri jika anaknya akan dijadikan pembantu atau melakukan pernikahan kontrak dengan orang asing dan cara yang terakhir adalah dengan memperdaya korban yang bekerja di tempat tertentu, tapi kemudian justru dijual di kawasan prostitusi, Kebanyakan korban dari tindak kejahatan ini adalah wanita, karena sindikat ini biasanya bekerjasama dengan tempat prostitusi, kasino (tempat judi), dan panti pijat ++ .

Untuk laki-laki sendiri biasanya akan dijadikan seorang budak atau pekerja lapangan yang mendapatkan upah kecil dengan pekerjaan yang berat. Dengan kata lain mereka biasanya dijadikan budak, harus mengikuti aturan dari Land Lord tersebut. Jikalau membangkang maka akan mendapatkan siksaan ataupun bahkan bisa di telantarkan. Perdagangan orang ini sangat marak terjadi di negara-negara berkembang dan miskin, dimana pemerintah kurang peduli terhadap kehidupan masyarakat nya. Dan bahkan oknum dari pemerintahan nya sendiri yang ikut dalam sindikat bisnis perdagangan orang.

Meskipun memiliki hubungan dekat, perdagangan manusia dan penyelundupan manusia adalah dua perilaku dan konsep yang berbeda. Perdagangan orang adalah suatu tindak pidana atau serangkaian tindak pidana yang terdiri dari tiga kegiatan, yaitu proses, cara, dan tujuan (UU RI No 21 Tahun 2007).

Perdagangan manusia biasanya melibatkan jaringan individu dari berbagai negara dan tidak terbatas pada satu negara. Karena merupakan operasi global, perdagangan manusia semakin menyamarkan batas wilayah antar negara, bisa negara tetangga atau negara dari wilayah yang berbeda. Hal ini menghambat kerja sama antar negara dalam upaya pencegahan dan pemberantasan perdagangan orang. Ketika perdagangan manusia terjadi di antara negara-negara yang berbeda, ini menyiratkan penyelundupan mungkin terlibat. Penyelundupan manusia dapat didefinisikan sebagai fasilitasi seseorang atau orang-orang yang melewati batasan internasional secara tidak sah untuk memasuki negara tujuan yang bukan warga negaranya sehingga fasilitator dapat menikmati keuntungan finansial, juga dapat melibatkan sindikat kriminal internasional (GAATW, 2014).

\section{Dasar Hukum serta Penegakan Tindak Pidana Penyelundupan dan Perdagangan Orang}

Aturan mengenai Penyelundupan Manusia dan Perdagangan Orang di Indonesia tercantum dalam beberapa aturan perundang-undangan, yakni UU Nomor 6 Tahun 2011, perihal Keimigrasian. Selanjutnya ada PP Nomor 31 Tahun 2013 perihal aturan Pelaksana UU No. 6 Tahun 2011 perihal Keimigrasian, UU No. 12 Tahun 2006 perihal Kewarganegaraan, UU No. 5 Tahun 2009 tentang Ratifikasi United Nations Convention Against Transnasional Organized Crime, UU Nomor 14 Tahun 2009 tentang Ratifikasi Protocol to Prevent, Suppress and Punish Trafficking in Persons, Especially Women and Children, Supplementing United Nations Convention Against Transnasional Organized Crime, UU Nomor 15 Tahun 2009 mengenai Ratifikasi Protocol Against The Smuggling of Migrants by Land, Sea and Air, Supplementing United Nations Convention Against 
Transnasional Organized Crime, UU No. 21 Tahun 2007 mengenai Tindak Pidana Perdagangan Orang.

Perlakuan terhadap korban penyelundupan dan perdagangan manusia telah diatur pada Pasal 86-90 UU No. 6 Tahun 2011, tapi ketentuan pasal-pasal tersebut tak mampu mencegah imigran gelap kembali melakukan penyelundupan. Premis yang dianut Protokol Penyelundupan Manusia adalah pengakuan yang didapat dari imigran gelap sebagai korban (korban) penculikan dan penyelundupan manusia, yakni seseorang yang dipaksa menjadi sasaran persepsi ekonomi melalui imajinasi. Tarik Australia keluar dari Indonesia. UNCATOC dan aturan formalitas Tambahannya adalah bentuk dari kesepakatan internasional yang mengikat beberapa negara yang mengikatnya serta memunculkan hak serta kewajiban untuk beberapa negara itu. tapi, perjanjian atau kesepakatan internasional tidak mengikat kesepakatan, karena kewajiban untuk melaksanakan perjanjian atau kesepakatan internasional bergantung pada ketentuan perundang-undangan nasional dari negara yang bersangkutan, hal itu disampaikan oleh Boer Mauna.

Perlakuan terhadap imigran gelap di Indonesia selama ini didasarkan pada perundang-undangan imigrasi, Undang-Undang No.6 Tahun 2011, yang menerapkan beberapa prinsip United Nations Convention against Transnational Organized Crime dan 2 aturan tambahannya. Berdasar pada Undang-Undang Keimigrasian, negara dikatakan berhak mengatur orang asing yang berada di wilayah NKRI. hak Indonesia sebagai negara yang berdaulat adalah mengontrol keberadaan para imigran gelap tersebut, baik yang tidak mempunyai dokumen ataupun yang memiliki dokumen.

Tapi, implementasinya menunjukkan bahwa undang-undang tersebut tidak mampu mengatur secara efektif keberadaan imigran gelap yang ada di wilayah Indonesia. Penggunaan kata imigran gelap atau ilegal menunjukkan bahwa para pencari suaka dan pengungsi masih belum dianggap sebagai pengungsi dan masih dianggap seperti kategori imigran pada umumnya. Imigrasi Indonesia menolak untuk mengklasifikasikan pengungsi dan pencari suaka sebagai imigran non-ilegal karena Indonesia belum meratifikasi Konvensi Pengungsi 1951.

UU No. 6 Tahun 2011 menyebutkan Penyelundupan Manusia (people smuggling) pada Pasal 1 Angka 32 yang dapat didefinisikan secara umum yakni, Penyelundupan manusia ialah suatu tindakan yang memiliki tujuan untuk memperoleh keuntungan, baik itu lisan maupun tak langsung, untuk pribadi atau orang lain yang merupakan orang dari sekelompok orang, terorganisir atau tidak terorganisir atau tidak terorganisir, yang bukan merupakan hukum negara Indonesia. terletak di/dari negara negara lain tetapi orang tersebut tidak berhak untuk meninggalkannya, tetapi negara negara tersebut diterbitkan tetapi tidak terbuka untuk pemeriksaan keimigrasian.
Sedangkan UU No. 21 Tahun 2007 perihal Tindak Pidana Perdagangan Orang Pasal 1 secara umum dapat dikatakan secara umum yaitu Perdagangan orang adalah perbuatan mengangkut, menyimpan, menyerahkan, menerima atau memindahkan seseorang disertai ancaman dan atau kekerasan, penculikan, pemenjaraan, penipuan, pemalsuan, anggota ajepositanperauranuan, anggota badan penipuan atjekuyalahor atjekuyalakuana anggota anggota penipuan dari seseorang yang mengendalikan orang lain, dari dalam atau berada di antara negara-negara, yang memiliki tujuan mengeksploitasi atau memaksa orang untuk melakukan eksploitasi.

\section{Pertanggungjawaban Pidana Pelaku Tindak Pidana Penyelundupan Manusia Dan Perdagangan Orang}

Penyelundupan serta perdagangan manusia merupakan tindak kejahatan yang terorganisir lintas batas dan melibatkan orang-orang dengan peran khusus yang berbeda. Level pertama yang paling rendah adalah belut yakni eksekutor atau pelaksana di lapangan, level kedua adalah koordinator, tugasnya mengawasi kegiatan di lapangan, dan di level ketiga ada pengontrol yang mengatur kegiatan para koordinator di lapangan. Dalam beberapa kasus, tidak semua orang yang diselundupkan atau dijual adalah imigran gelap murni. Beberapa di antaranya memiliki peran lebih dari satu yakni sebagai korban yang dijual atau diselundupkan dan sekaligus bertindak sebagai penyelundup atau penjual (smuggler/penjual).

karena itu perlu pembeda untuk tugas-tugas pelaku, meninjau dari kesalahan mana yang sudah dilakukan oleh pelaku dan untuk bisa menentukan pertanggungjawaban tindak pidana dari kejahatan tersebut. Anehnya, ini kemudian ditemukan dalam beberapa kasus perdagangan manusia, yang banyak di antaranya adalah pejabat pemerintah. Mereka menyalahgunakan kekuasaan dan wewenangnya untuk mempromosikan perdagangan manusia dan perdagangan manusia.

Pertanggungjawaban pidana orang yang melakukan tindak pidana penyelundupan orang dan perdagangan manusia didasarkan pada ketentuan UU No. 6 Tahun 2011 mengenai Keimigrasian. Hal ini diatur pada alinea ke-satu pasal 120: "Setiap orang yang menyelundupkan orang dipidana dengan pidana penjara paling singkat 5 tahun dan paling lama 15 tahun dan denda paling sedikit Rp. 500.000 .000 dan maksimal Rp. 1500.000 000.-". hukum yang sama juga dikenakan pada percobaan untuk melakukan kejahatan ini, sebagaimana yang sudah diatur pada Pasal 120 ayat ke2. Adapun tindak pidana penyelundupan manusia yang dilakukan oleh perusahaan hanya denda dengan jumlah yang ditentukan pidana 3 (tiga) kali lipat (Pasal 136 ayat (2)).

Untuk perdagangan manusia sendiri tercantum pada UU No. 6 Tahun 2011 perihal Keimigrasian yang 
tidak mengatur terlalu spesifik, tetapi pada Pasal 13 dijelaskan bahwa bagi Orang Asing yang terlibat dengan perdagangan orang tidak dapat diizinkan memasuki wilayah Indonesia. namun dalam UU No. 21 Tahun 2007 perihal Pemberantasan Tindak Pidana Perdagangan manusia Pasal 2:

"Setiap orang yang melakukan perekrutan, pengangkutan, penampungan, pengiriman, pemindahan, atau penerimaan seseorang dengan ancaman kekerasan, penggunaan kekerasan, penculikan, penyekapan, pemalsuan, penipuan, penyalahgunaan kekuasaan atau posisi rentan, penjeratan utang atau memberi bayaran atau manfaat walaupun memperoleh persetujuan dari orang yang memegang kendali atas orang lain, untuk tujuan mengeksploitasi orang tersebut di wilayah negara Republik Indonesia, dipidana dengan pidana penjara paling singkat 3 (tiga) tahun dan paling lama 15 (lima belas) tahun dan pidana denda paling sedikit Rp120.000.000,00 (seratus dua puluh juta rupiah) dan paling banyak Rp600.000.000,00 (enam ratus juta rupiah)."

\section{SIMPULAN}

Kemiskinan merupaan satu dari banyak faktor yang paling dominan (utama) pada perkembangan tindak kejahatan ini perdagangan orang dan penyelundupan manusia. People smuggling sesungguhya ada karena terdapatnya dorongan dari dalam diri sendiri untuk menjadi seorang imigran gelap (ilegal). Sedangkan kejahatan perdagangan orang (human trafficking) ini, pelaku menggunakan berbagai jalan demi kelancaran kejahatannya, ada yang menculik dan kemudian menjual ketempat prostitusi luar negeri, ada pula korban yang dijual oleh keluarganya sendiri dengan keyakinan bahwa anaknya akan dijadikan Asisten rumah tangga / pembantu atau melakukan pernikahan kontrak dengan warga negara asing (WNA) dan cara terakhirnya adalah dengan memperdaya korban yang bekerja di tempat tertentu. Aturan mengenai Penyelundupan Manusia dan Perdagangan Orang di Indonesia tercantum dalam beberapa aturan perundang-undangan, yakni UU Nomor 6 Tahun 2011, perihal Keimigrasian. Selanjutnya ada PP Nomor 31 Tahun 2013 perihal aturan Pelaksana UU No. 6 Tahun 2011 perihal Keimigrasian, UU No. 12 Tahun 2006 perihal Kewarganegaraan, UU No. 5 Tahun 2009 tentang Ratifikasi United Nations Convention Against Transnasional Organized Crime, UU Nomor 14 Tahun 2009 tentang Ratifikasi Protocol to Prevent, Suppress and Punish Trafficking in Persons, Especially Women and Children, Supplementing United Nations Convention Against Transnasional Organized Crime, UU Nomor 15 Tahun 2009 mengenai Ratifikasi Protocol Against The Smuggling of Migrants by Land, Sea and Air, Supplementing United Nations Convention Against Transnasional Organized Crime, UU No. 21 Tahun
2007 mengenai Tindak Pidana Perdagangan Orang. Pertanggungjawaban pidana orang yang melakukan tindak pidana penyelundupan orang dan perdagangan manusia didasarkan pada ketentuan UU No. 6 Tahun 2011 mengenai Keimigrasian.

\section{DAFTAR PUSTAKA}

Fernando, Sam. (2013). Politik Hukum Pemerintah (Direktorat Jenderal Imigrasi) Dalam Menanggulangi Masalah Penyelundupan Manusia. Fakultas Hukum. Universitas Brawijaya

Gallagher, A. T. (2014). The International Law of Migrant Smuggling. Cambridge: Cambridge University Press.

Global Alliance Against Traffic in Women (GAATW). (2011). Smuggling and Trafficking: Rights and Intersection. Bangkok: GAATW.

Nasution, A. (2017). Ancaman Keamanan Maritim Indonesia. Diakses melalui http://ruangrakyat.com/ancaman-keamananmaritim-indonesia/

UU No. 6 Tahun 2011 tentang Keimigrasian

UU No. 21 Tahun 2007 tentang Tindak Pidana Perdagangan Orang 